\title{
Pengetahuan Konsumen dan Keputusan Menjadi Nasabah (Kasus BSM Kan.Cab Pembantu BSD Tangerang Selatan)
}

\author{
Oleh: \\ Sunardi \\ Ana Maftukhah
}

Sekolah Tinggi Ekonomi Syariah (STES) Islamic Village Tangerang
Jl. Raya Islamic Kelapa Dua Tangerang 15810, Indonesia

\begin{abstract}
Abstrak: Penelitian ini bertujuan untuk mengetahui pengetahuan konsumen memberikan pengaruh terhadap pengambilan keputusan untuk menjadi nasabah pada PT. Bank Syariah Mandiri KCP BSD Tangerang Selatan. Metode yang digunakan dalam penelitian ini adalah penelitian kuantitatif, disebut penelitian kuantitatif dikarenakan data penelitian berupa angka-angka dan analisis menggunakan statistik. Alat uji yang digunakan dalam penelitian ini yaitu dengan menggunakan metode regresi linier sederhana, dengan metode ini akan didapat pengaruh variabel bebas (Pengetahuan Konsumen) terhadap variabel terikat (Pengambilan Keputusan Menjadi Nasabah), dan yang menjadi sampel pada penelitian ini adalah nasabah dana pihak ketiga pada PT. Bank Syariah Mandiri KCP BSD Tangerang Selatan sebanyak 30 orang, pengambilan sampel menggunakan teknik Non Probability Sampling dengan metode Purposive Sampling adalah metode pengambilan sampel secara sengaja sesuai dengan persyaratan sampel yang diperlukan atau secara sengaja mengambil sampel tertentu, dan peneliti mengambil 30 responden sebagai sampel penelitian. Kemudian dilakukan pengujian validitas dan realiabilitas terhadap data yang diperoleh. Hasil penelitian ini menunjukkan bahwa pengetahuan konsumen berpengaruh terhadap keputusan konsumen sebesar 63,2 \%, sedangkan sisanya 36,8\% dipengaruhi oleh faktor lain diluar variable X (Pengetahuan Konsumen) yang tidak diteliti.
\end{abstract}

Kata kunci: Pengetahuan Konsumen, Bank Syariah, Keputusan Konsumen (Nasabah).

\section{Pendahuluan}

Dewasa ini permintaan masyarakat di Indonesia akan jasa Perbankan Syariah yang semakin meningkat mendorong para pelaku bisnis Perbankan untuk membuka bank yang didasarkan pada prinsip Syariah. Adanya Perbankan Syariah-Syariah di Indonesia dipelopori oleh berdirinya Bank Muamalat Indonesia yang diprakarsai oleh Majelis Ulama Indonesia (MUI) dengan tujuan mengakomodir berbagai aspirasi dan 
pendapat di masyarakat terutama masyarakat Islam yang banyak berpendapat bahwa bunga bank itu haram karena termasuk riba (Abdullah, 2002: 35).

Mengikuti jejak Bank Muamalat Indonesia, tidak sedikit bank konvensional yang juga membuka pelayanan jasa Perbankan Syariah. Sebut saja Bank Syariah Mandiri, Bank BNI Syariah, Bank Mega Syariah, Bank Syariah Bukopin, BRI Syariah, CIMB Niaga Syariah dan lain-lain. Di samping bank-bank besar berskala nasional, usaha keuangan Syariah di tingkat mikro juga tumbuh pesat di berbagai daerah. Saat ini terdapat 11 Bank Umum Syariah di Indonesia, 23 unit usaha Syariah, dan 151 bank perkreditan rakyat Syariah (Abdullah, 2002: 47).

Sedikitnya ada 4 hal yang menjadi tujuan pengembangan Perbankan yang berdasarkan prinsip Syariah Islam, yaitu (1) memenuhi kebutuhan jasa Perbankan bagi masyarakat yang tidak dapat menerima konsep bunga; (2) terciptanya dual banking system di Indonesia yang mengakomodasikan baik Perbankan konvensional maupun Perbankan Syariah yang akan melahirkan kompetisi yang sehat dan perilaku bisnis yang berdasarkan nilai-nilai moral; (3) mengurangi risiko sistemik dari kegagalan sistem keuangan di Indonesia; (4) mendorong peran Perbankan dalam menggerakkan sektor riil dan membatasi spekulasi atau tidak produktif karena pembiayaan ditujukan pada usaha-usaha yang berlandaskan nilai-nilai moral (Idat, 2005: 3).

\section{Tantangan Bank Syariah}

Salah satu tantangan yang kini banyak dihadapi dan paling berat adalah banyaknya tudingan yang mengatakan Bank Syariah hanya sekedar Perbankan konvensional yang ditambah label Syariah. Tantangan lainnya adalah bagaimana menonjolkan ciri khas Perbankan Syariah, yakni bank yang secara langsung membangun sektor riil dengan prinsip keadilan. Selain itu, dari aspek eksternal, Sektor Perbankan Syariah memiliki tantangan dari sisi pemahaman sebagian masyarakat yang masih rendah terhadap operasional Bank Syariah. Mereka secara sederhana beranggapan bahwa dengan tidak dijalankannya sistem bunga, Bank Syariah tidak akan memperoleh pendapatan. Konsekuensinya adalah Bank Syariah akan sulit untuk survive.

Pemahaman yang rendah terhadap Perbankan Syariah salah satunya diakibatkan masih kurangnya iklan yang dilakukan Bank Syariah. Banyak masyarakat yang belum memahami secara benar apa itu lembaga keuangan Syariah, sistem yang dipakai, jenis produknya, serta apa keunggulan lembaga keuangan Syariah bila dibandingkan dengan lembaga keuangan konvensional. Dengan demikian hal tersebut 
mempengaruhi persepsi dan sikap masyarakat terhadap Bank Syariah. Maka tugas penting yang harus dilakukan oleh pengelola Bank Syariah adalah meningkatkan promosi berupa iklan Bank Syariah melalui media massa yang efektif, sehingga pengetahuan masyarakat mengenai Bank Syariah tidak hanya terbatas pada bank yang menggunakan sistem bagi hasil (Bank Indonesia dan Lembaga Penelitian IPB, 2003).

Tidak sedikit masyarakat yang belum mengetahui dengan jelas mengenai jenis produk, manfaat dan prinsip kerja Bank Syariah sehingga mereka merasa bingung ketika akan menggunakannya atau tidak menggunakan fasilitas yang ada pada produk karena tidak mengetahuinya. Terlebih lagi istilah-istilah produk dan layanan Perbankan Syariah menggunakan bahasa Arab. Dalam produk penghimpunan dana atau tabungan terdapat sistem bagi hasil yang dikenal dengan istilah mudharabah dan musyarakah, sistem titipan atau deposito dikenal dengan istilah wadiah. Dalam penyaluran dana terdapat sistem jual beli atau dikenal dengan nama murabahah, ada pula sistem sewa beli yang dinamakan ijarah wa iqtina serta ada sistem pinjaman yang disebut dengan qardh (Rammal, 2007: 12).

Oleh karena itu upaya untuk meningkatkan pengetahuan masyarakat tentang Bank Syariah menjadi isu strategis dalam pengembangan Bank Syariah di masa yang akan datang. Semakin baik pengetahuan tentang Bank Syariah semakin tinggi kemungkinan untuk mengadopsi Bank Syariah. Sebagian besar masyarakat yang mengadopsi Bank Syariah masih dominan dipengaruhi oleh emosi keagamaan belum berdasarkan pada pemahaman rasional yang baik, sehingga pengetahuan masyarakat mengenai Bank Syariah tidak hanya terbatas pada bank yang menggunakan sistem bagi hasil.

Di samping pengetahuan masyarakat mengenai Perbankan Syariah, faktor komitmen keagamaan (religious commitment) dan iklan yang dilakukan oleh pihak Bank Syariah juga memiliki andil dalam membentuk minat seseorang untuk menabung atau berinvestasi di Bank Syariah. Iklan mengenai Bank Syariah di berbagai media massa selain dapat secara langsung mempengaruhi minat berinvestasi di Bank Syariah juga dapat mempengaruhi pengetahuan masyarakat mengenai Perbankan Syariah (Rammal, 2007: 12).

Muhammad (2007: 73), menyatakan ada beberapa yang mempengaruhi pengetahuan mengenai Perbankan Syariah, yaitu: agama, keberadaan Bank Syariah, pendapat tentang bunga bank, pendidikan, jenis pekerjaan, level pendapatan, referensi Bank Syariah dan fasilitas Bank Syariah. Meskipun mayoritas penduduk Indonesia adalah muslim, banyak yang tidak mengetahui sama sekali mengenai produk-produk 
yang ditawarkan oleh Bank Syariah, hal tersebut membuat calon nasabah merasa kurang berminat menabung di Bank Syariah. Sebaliknya, minat menabung akan timbul jika pengetahuan mengenai produk dan jasa Perbankan tersebut sudah diketahui dengan baik karena pelanggan dapat menggunakan dan memanfaatkan fasilitas dari bank tersebut. Menurut Sutjipto (2001: 97), Minat adalah kesadaran seseorang terhadap suatu objek, orang, masalah atau situasi yang mempunyai kaitan dengan dirinya. Minat harus dipandang sebagai sesuatu yang sadar.

\section{Perilaku Konsumen}

Pengertian perilaku konsumen menurut Mangkunegara perilaku konsumen merupakan suatu tindakan-tindakan yang dilakukan oleh individu, kelompok atau organisasi yang berhubungan dengan proses pengambilan keputusan dalam mendapatkan, dan menggunakan barangbarang atau jasa ekonomi yang dapat dipengaruhi oleh lingkungan (Mangkunegara, 2009: 14).

Sedangkan menurut Kotler dan Keller perilaku konsumen adalah studi tentang bagaimana individu, kelompok, dan organisasi memilih, membeli, menggunakan, dan bagaimana barang, jasa, ide, atau pengalaman untuk memuaskan kebutuhan dan keinginan mereka (Kotler, 2008: 166).

Peter J. Paul dan Jerry C Olson menyatakan bahwa perilaku konsumen merupakan interaksi dinamis antara pengaruh dan kondisi perilaku dan kejadian di sekitar lingkungan di mana manusia melakukan aspek pertukaran dalam kehidupan mereka (Peter, 2006: 16).

Dari beberapa definisi di atas dapat di lihat ada dua hal penting dari perilaku konsumen yaitu proses pengambilan keputusan dan kegiatan fisik yang semuanya ini melibatkan individu dalam menilai, mendapatkan dan mempergunakan barang-barang dan jasa secara ekonomis. Dengan kata lain perilaku konsumen adalah ilmu yang mempelajari tingkah laku konsumen dalam arti tindakan-tindakan yang dilakukan untuk membeli suatu barang dan jasa.

\section{Faktor-faktor yang Mempengaruhi Perilaku Pembelian Konsumen}

Perilaku permintaan konsumen terhadap barang dan jasa akan dipengaruhi oleh beberapa faktor di antaranya: pendapatan, selera konsumen, dan harga barang, di saat kondisi yang lain tidak berubah (cateris paribus) perilaku konsumen ini didasarkan pada teori perilaku konsumen yang menjelaskan bagaimana seseorang dengan pendapatan yang diperolehnya dapat membeli berbagai barang dan jasa sehingga 
tercapai kepuasan tertentu sesuai dengan apa yang diharapkan (Nugroho, 2000: 42).

Sedangkan menurut Philip Kotler perilaku konsumen dipengaruhi oleh beberapa faktor di antaranya, yaitu:

\section{Faktor budaya}

Faktor budaya merupakan hal yang sangat penting dalam perilaku pembelian yang mana faktor budaya ini terdiri dari budaya dan kelas sosial. Budaya merupakan penentu keinginan dan perilaku yang paling dasar. Kelas sosial merupakan pembagian dalam masyarakat yang relatif homogen dan permanen, yang tersusun secara hirarkis dan para anggotanya menganut nilai, minat, dan perilaku yang serupa.

\section{Faktor sosial}

Faktor sosial dipengaruhi oleh:

a. Kelompok acuan: seseorang terdiri dari semua kelompok yeng memiliki pengaruh langsung atau tidak langsung terhadap sikap atau perilaku seseorang tersebut.

b. Keluarga: merupakan organisasi pembelian konsumen yang paling penting dalam masyarakat, dan anggota para keluarga menjadi kelompok acuan primer yang paling berpengaruh.

c. Peran dan status sosial: peran meliputi kegiatan yang diharapkan akan dilakukan oleh seseorang, masing-masing peran menghasilkan status.

\section{Faktor Pribadi}

Karakteristik faktor pribadi meliputi :

a. Usia dan tahap siklus hidup: orang membeli barang dan jasa berbeda-beda sepanjang hidupnya.

b. Pekerjaan dan lingkungan ekonomi

c. Gaya hidup: pola hidup seseorang di dunia yang terungkap pada aktivitas, minat dan opininya.

d. Kepribadian dan konsep diri.

\section{Faktor Psikologis}

Pilihan membeli seseorang dipengaruhi oleh empat faktor psikologis utama yaitu:
a. Motivasi
b. Persepsi Konsumen
c. Sikap Konsumen

\section{Pengetahuan Konsumen}

Pengetahuan konsumen adalah semua informasi yang dimiliki konsumen mengenai berbagai macam produk dan jasa, serta pengetahuan 
lainnya yang terkait dengan produk dan jasa tersebut dan informasi yang berhubungan dengan fungsinya sebagai konsumen. Pengetahuan konsumen akan mempengaruhi keputusan pembelian (Sumarwan, 2011: 310).

Menurut Philip Kotler yang dialih bahasakan oleh Hendra Teguh, Ronny A Rusli dan Benyamin Molan (2000: ) menyebutkan: "Pengetahuan adalah suatu perubahan dalam perilaku suatu individu yang berasal dari pengalaman." Konsumen memiliki tingkatan pengetahuan produk yang berbeda, yang dapat dipergunakan untuk menerjemahkan informasi baru dan membuat pilihan keputusan. Menurut J Paul Peter, Jerry C. Olson dialih bahasakan oleh Damos Sihombing (2006: 86) membagi pengetahuan menjadi 3 jenis pengetahuan produk yaitu :

a. Pengetahuan tentang karakteristik atau atribut produk/jasa.

b. pengetahuan tentang manfaat produk/jasa.

c. Pengetahuan tentang kepuasan yang diberikan oleh produk/jasa bagi konsumen

Semakin meningkatnya persaingan dalam dunia Perbankan maka bank-Bank Syariah mendorong untuk lebih berorientasi kepada konsumen atau nasabah. Untuk mendukung upaya tersebut diperlukan pengetahuan mengenai konsumen terutama perilakunya. Setidaknya ada dua alasan mengapa perilaku konsumen perlu dipahami:

a. Dengan memahami konsumen akan menuntun pemasar kepada kebijakan pemasaran yang tepat dan efisien.

b. Diharapkan dengan berorientsi kepada konsumen, pemasar dapat melakukan strategi yang baik dalam mensiasati kelebihan penawaran dari pada permintaan di dunia bisnis.

Menurut John C Mowen Michael Minor dialih bahasakan oleh Lina Salim (2002) menjelaskan : "Perilaku konsumen adalah studi tentang unit pembelian dan proses pertukaran yang melibatkan perolehan, konsumsi, dan pembuangan barang/jasa, pengalaman serta ide-ide".

Dalam mengkonsumsi suatu produk, konsumen cenderung memilih produk yang memberikan nilai atau manfaat yang lebih dibandingkan dengan produk lainnya. Keputusan konsumen timbul karena adanya penilaian yang objektif atau karena dorongan emosi. Keputusan untuk bertindak adalah berasal dari serangkaian aktivitas dan rangsangan mental dan emosional. Keputusan yang rumit sering melibatkan beberapa keputusan (decision) melibatkan pilihan diantara dua atau lebih alternatif. Keputusan selalu mensyaratkan pilihan diantara beberapa perilaku yang berbeda. (Nugroho J Setiadi, 2003: 80).

\section{Bank Syariah}


Menurut Muhammad, Bank Syariah adalah lembaga keuangan negara yang memberikan pembiayaan dan jasa-jasa lainnya di dalam lalu lintas pembayaran dan juga peredaran uang yang beroperasi dengan menggunakan Prinsip-prinsip Syariah atau Islam. Sedangkan menurut Mudrajat Kuncoro dan Suharjono, Bank Syariah adalah bank yang beroprasi sesuai dengan Prinsip Syariah Islam, menghindari praktek yang mengandung unsur riba (Mia Lasmi, 2013: 76-77).

Dari pendapat diatas dapat diambil kesimpulan bahwa Bank Syariah adalah bank yang sistem Perbankannya menganut Prinsip-prinsip dalam Islam. Bank Syariah merupakan bank yang dijalankan sesuai dengan ajaran-ajaran Agama Islam yang seharusnya dapat diterima oleh umat Islam. Perbankan Syariah ialah bank yang berdasarkan Prinsip Syariah dalam penentuan harga produknya sangat berbeda dengan bank konvensional. Bank Syariah mengharamkan penggunaan harga produknya dengan bunga tertentu. melainkan mengacu kepada ketentuan-ketentuan Al-Qur'an dan Hadist.

Menurut Undang-Undang No.21 tahun 2008 Tentang Perbankan Syariah, Bank Syariah adalah bank yang menjalankan kegiatan usahanya berdasarkan Prinsip Syariah dan menurut jenisnya terdiri atas bank umum Syariah dan Bank Pembiayaan Rakyat Syariah.

Bank Syariah lahir sebagai salah satu solusi alternatif terhadap persoalan pertentangan antara bunga bank dengan riba pada sebagian masyarakat kita. Bank Islam lahir di Indonesia sekitar tahun 1990 yang direvisi dengan Undang-Undang Perbankan Nomor 10 tahun 1998 tentang Perbankan dalam bentuk sebuah bank dengan sistem bagi hasil atau Bank Syariah. Munculnya Bank Syariah karena situasi dan keadaan yang terkait dengan perangkat bunga yang dikembangkan oleh bank konvensional yang menjadikan ganjalan di sebagian masyarakat kita dan harus segera ditemukan pemecahannya.

Bank Syariah memberikan pembiayaan kepada nasabahnya tidak dengan membungakan uang tersebut melainkan dengan menggunakan Prinsip-prinsip Syariah. Prinsip Syariah adalah aturan perjanjian berdasarkan hukum Islam antara bank dengan pihak lain untuk penyimpanan dana dan atau pembiayaan kegiatan usaha atau kegiatan lainnya yang sesuai dengan Syariah. Prinsip-prinsip Syariah tersebut adalah sebagai berikut: Prinsip Bagi Hasil, Prinsip Jual Beli, Prinsip Sewa Menyewa, Prinsip Titipan dan Simpanan, Prinsip Tabarru'.

Atribut berupa fitur produk yang dimiliki Bank Syariah adalah berupa Prinsip-prinsip dasar sistem keuangan Islam yang berasal dari AlQuran dan As-Sunnah. Prinsip-prinsip dasar tersebut dapat disimpulkan sebagai berikut. Pengharaman Bunga, Pembagian Risiko, Uang Sebagai 
Modal Potensial, Larangan Perilaku Spekulatif, Kehalalan Kontrak, dan Kegiatan Sesuai Syariah.

Prinsip-prinsip dasar dalam sistem keuangan Islam yang dikemukakan oleh iqbal (1997), dalam penelitian ini dijadikan sebagai atribut produk khas yang seharusnya ada pada produk Bank Syariah, diantaranya: (1) Tidak ada unsur riba, (2) Menggunakan sistem bagi hasil, (3) Tidak ada unsur ketidakpastian (ghoror), (4) Tidak ada unsur judi (maysir), (5) Digunakan untuk investasi yang halal.

Atribut-atribut produk khas tersebut yang menjadi alasan pokok para nasabah yang beragama Islam memilih menggunakan Bank Syariah dan menjadi indikator penilaian bagi nasabah. Jika atribut-atribut khas tersebut melekat pada PT. Bank Syariah Mandiri KCP BSD Tangerang Selatan dan dirasakan manfaatnya oleh nasabah maka nasabah akan memberikan penilaian positif atas atribut produk Islam tersebut.

\section{Keputusan Konsumen}

Pemasar perlu fokus pada seluruh proses pengambilan keputusan bukan hanya proses pembelianya saja. Oleh karena itu kita perlu mengetahui definisi keputusan pembelian menurut beberapa ahli.

Menurut Kotler dan Keller proses keputusan pembelian merupakan proses di mana konsumen melewati lima tahap yaitu: tahap pengenalan masalah, pencarian informasi, evaluasi alternatif, keputusan pembelian, pasca pembelian dan perilaku pasca pembelian, yang dimulai jauh sebelum pembelian aktual dilakukan dan memiliki dampak yang lama setelah itu (Kotler dan Keller, 2008: 227).

Dari pengertian di atas dapat disimpulkan bahwa keputusan pembelian merupakan tahap pemilihan yang dilakukan konsumen dalam pengambilan keputusan dalam membeli suatu produk.

\section{Proses Pengambilan Keputusan Konsumen}

Proses pengambilan keputusan membeli mengacu pada tindakan konsisten dan bijaksana yang dilakukan untuk memenuhi kebutuhan. Keputusan pembelian sebagai pemilihan suatu tindakan dari dua atau lebih pilihan alternatif. Seorang konsumen yang hendak melakukan pilihan maka mereka memiliki pilihan alternatif, jika konsumen sudah memutuskan alternatif yang akan dipilih dan mungkin penggantinya jika diperlukan maka ia akan melakukan pembelian. Pembelian meliputi keputusan mengenai apa yang akan dibeli, apakah membeli atau tidak, kapan membeli, di mana membeli dan bagaimana cara membayarnya. Dalam melakukan pembelian terdapat beberapa tahap yag dilalui 
konsumen dalam proses pengambilan keputusan yaitu seperti terlihat pada gambar berikut (Sciffman, 2004: 289):

Gambar: 2.1 Proses Keputusan Pembelian (Kotler dan Keller, 2008: 201206)

Suatu proses keputusan membeli bukan sekedar mengetahui berbagai faktor yang akan mempengaruhi pembeli, tetapi berdasarkan peranan dalam pembelian dan keputusan untuk membeli. Terdapat lima peran yang terjadi dalam keputusan membeli:

1) Pemrakarsa (Initiator): orang yang pertama-tama memberikan pendapat atau pikiran untuk memberikan pendapat atau pikiran untuk membeli produk atau jasa tertentu.

2) Pemberi pengaruh (influencer): orang yang pandangan/ nasihatnya memberi bobot dalam pengambilan keputusan akhir.

3) Pengambil keputusan (decider): orang yang sangat menentukan sebagian atau keseluruhan pembelian; apakah membeli, apa yang akan dibeli, kapan hendak dibeli, degan cara bagaimana membeli, atau di mana akan membeli.

4) Pembeli (buyer): orang yang melakukan pembelian nyata.

5) Pemakai (user): orang yang mengkonsumsi atau menggunakan produk atau jasa (Bilson, 2002: 15).

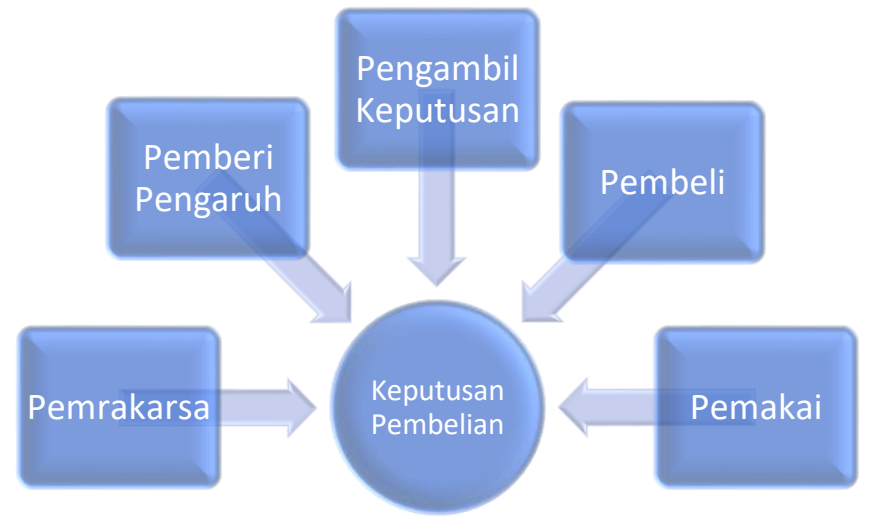


Gambar: 2.2 peran-peran pembelian konsumen (Philip Kotler, 2009:

\section{Metode Penelitian}

$$
\text { 264). }
$$

Penelitian ini menggunakan penelitian kuantitatif, karena permasalahan penelitian sudah jelas dan peneliti ingin mendapatkan informasi yang lebih luas dan nyata. Penelitian ini berjudul pengaruh pengetahuan konsumen tentang Perbankan Syariah terhadap keputusan menjadi nasabah pada PT. Bank Syariah Mandiri Kantor Cabang BSD Tangerang Selatan.

Data yang digunakan dalam penelitian ini adalah data primer dan data sekunder. Data primer, pengumpulan data primer dilakukan dengan cara menyebarkan kuesioner pada nasabah dana pihak ketiga PT. Bank Syariah Mandiri Kantor Cabang Pembantu BSD yang terletak di Jl. Letnan Sutopo Sektor XIV Kelurahan Rawa Mekar Jaya Kecamatan Tangerang Selatan. Sedangkan data sekunder, yaitu data yang telah ada dan tersusun secara sistematis serta merupakan hasil penelitan atau rangkuman dari dokumen-dokumen perusahaan serta literatur lain seperti buku, majalah, surat kabar, makalah, dan situs web.

\section{Populasi dan Sampel}

Populasi dalam penelitian ini adalah nasabah dana pihak ketiga PT. Bank Syariah Mandiri Cabang BSD Tangerang Selatan. Informasi yang diperolah besarnya populasi nasabah Dana Pihak Ketiga berjumlah 5.350 nasabah dengan perincian sebagai berikut:

\section{Tabel 3.1}

Total Nasabah KCP Tangerang BSD Per 31 Agustus 2015

$\begin{array}{ll}\text { Total Deposito } & 320 \\ \text { Total Giro } & 125 \\ \text { Total Tabungan } & 4.905 \\ \text { Total } & 5.350\end{array}$

\section{Sampel}

Penelitian ini menggunakan teknik pengambilan sampel Non Probability Sampling. Meski seharusnya yang mewakili (representatif) dari isi populasi tersebut di atas adalah 98 responden/nasabah, peneliti berharap dengan menggunakan metode Purposive Sampling, kriteria sampel yang diperoleh yaitu 30 responden benar-benar sesuai dengan penelitian yang dilakukan. 
Dalam penelitian ini pengetahuan konsumen adalah variabel bebas (X). dan keputusan konsumen adalah sebagai variabel terikat $(\mathrm{Y})$.

\section{Skala Pengukuran Variabel}

Variabel pengetahuan konsumen (X) dengan indikator pengetahuan tentang karakteristik atau atribut produk atau jasa, faktor yang melekat secara langsung pada produk atau jasa, faktor yang melekat secara tidak langsung pada produk atau jasa, dan pengetahuan manfaat produk atau jasa (Manfaat Fungsional, Manfaat Psikososial).

Pengukuran variabel keputusan konsumen $(\mathrm{Y})$ dengan indikator pengenalan masalah/kebutuhan, pencarian informasi, evaluasi alternatif dan keputusan pembelian menggunakan skala likert dengan lima tingkatan yang diberi skor.

\section{Teknik Analisis Data}

Analisis data dilakukan dengan cara yaitu analisis Kuantitatif. yang dilakukan terhadap kuesioner yang dipakai dalam penelitian adalah: Uji Validitas, Uji Reliabilitas, Statistik Deskriptif, Uji Asumsi Klasik. Uji Regresi Linear Sederhana, Uji Hipotesis

\section{Pengetahuan Konsumen Tentang Perbankan Syariah Pada PT. Bank Syariah Mandiri KCP BSD Tangerang Selatan}

Keputusan konsumen terhadap pengetahuan konsumen tentang Perbankan Syariah pada PT. Bank Syariah Mandiri KCP BSD Tangerang Selatan.

Tabel 4.1. Keseluruhan Indikator Pengetahuan Konsumen

Variabel Indikator

1.Pengetahuan

karakteristik atau atribut produk atau jasa

- Faktor yang melekat secara langsung pada produk atau jasa.

- Faktor yang melekat secara tidak langsung pada produk atau jasa.

2.Pengetahuan manfaat produk atau jasa

- Manfaat Fungsional
Total Skor Interprestasi

1.001 Setuju/Mengetahui

$507 \quad$ Setuju/Mengetahui

$494 \quad$ Setuju/Mengetahui

762 Setuju/Mengetahui 
- Manfaat Psikososial

3.Nilai kepuasan yang diperoleh dari produk atau jasa yang 854 Setuju/Mengetahui

ditawarkan perusahaan.

Sumber : Hasil dari Jawaban Indikator Variabel X

Pengaruh pengetahuan konsumen tentang Perbankan Syariah terhadap keputusan konsumen menjadi nasabah pada PT. Bank Syariah Mandiri KCP BSD Tangerang Selatan.

Tabel 4.2. Tabel Keseluruhan Indikator Keputusan Konsumen

Variabel Indikator

Pengenalan masalah

Pencarian informasi

Evaluasi alternatif

Keputusan Pembelian
Total Skor

Interprestasi

854

Setuju/Diperlukan

Sumber : Hasil dari Kuesioner Variabel Y

\section{Uji Validitas}

Dari hasil analisis didapat nilai korelasi antara skor item dengan skor total. Nilai ini kemudian dibandingkan dengan nilai $r$ hitung. Nilai $r$ tabel untuk degree of freedom (df) $=n-k-1$. Dalam hal ini $n$ adalah jumlah sampel dan k adalah konstruk. Pada kasus ini, besarnya df dapat dihitung 30-1-1 = 28 dengan alpha 0.05 (a 5\%), maka didapat nilai $r$ tabel sebesar 0,361 dengan jumlah total keseluruhan sampel sebanyak 30 responden dengan menggunakan uji 2 sisi (Priyatno, 2008: 121).

Berdasarkan perhitungan menggunakan SPSS seri 21 diperoleh hasil uji validitas terhadap pertanyaan yang digunakan untuk mengukur variabel Pengetahuan Konsumen dan Keputusan Nasabah. Berdasarkan hasil pengolahan data uji validitas variabel independen $(X)$ dan variabel dependen $(Y)$ diperoleh hasil $r$ hitung $>r$ tabel, yaitu $0,795>0,361$ dan nilai signifikan $(0,000)$ yang bernilai jauh dibawah 0,05 . Dengan demikian masing-masing butir pertanyaan dalam angket untuk variabel $\mathrm{X}$ dan $\mathrm{Y}$ dinyatakan valid.

\section{Uji Reliabilitas}


Uji reliabilitas digunakan untuk mengetahui apakah butir-butir pertanyaan dalam angket penelitian konsisten atau tidak. Suatu variabel diakatakan reliabel apabila memiliki Cronbach Alpha lebih besar dari 0,60 (Ghozali, 2005). Pengujian reliabilitas pada penelitian ini menggunakan Cronbach Alpha. Dalam menghitung reliabilitas kedua skala, peneliti menggunakan bantuan program SPSS (Statistikal Product and Service Solution) 21 for windows. Dari hasil pengujian didapatkan perhitungan koefisien Cronbach Alpha kedua variabel = lebih dari 0,703, artinya di atas $>0,60$. Dengan demikian dapat disimpulkan bahwa semua item pertanyaan baik dari variabel independen $(\mathrm{X})$ maupun variabel dependen (Y) adalah reliabel/reliabilitas (alpha $>0,7$ ).

\section{Statistik Deskriptif}

Sebelum dilakukan pengujian maka terlebih dahulu akan dilakukan statistik deskriptif. Statistik deskriptif menguraikan atau menggambarkan atau deskripsi suatu data yang dilihat dari rata-rata dan standar deviasi dari masing-masing variabel penelitian. Berikut adalah tabel statistik deskriptif di mana dengan tabel inilah bisa diketahui mean dan standar deviasi dari variabel pengetahuan konsumen dan keputusan menjadi nasabah. Dilihat dari 30 sampel penelitian maka nilai rata-rata variabel Keputusan Nasabah adalah 31.83 dengan standar deviasi 3.354, sedangkan nilai rata-rata variabel Pengetahuan Konsumen adalah 87,23 dengan standar deviasi 8.525.

\section{Uji Asumsi Klasik}

Pengujian asumsi klasik meliputi:

\section{Uji Normalitas Data}

Berdasarkan Normal Probability Plot of Residual, diketahui bahwa residual membentuk suatu plot garis lurus, sehingga dapat disimpulkan bahwa residual berdistribusi normal.

Berdasarkan Normal Histogram, terlihat bahwa membentuk kurva normal dan sebagian bar/batang berada dibawah kurva dan terlihat sebaran data secara umum membentuk lonceng, sehingga dapat disimpulkan bahwa variabel berdistribusi normal.

\section{Uji Autokorelasi}

Berdasarkan hasil, dapat dilihat apabila menggunakan uji DW, maka nilai DWhitung sebesar 2,524. Nilai DWhitung kemudian dibandingkan dengan nilai DWtabel. Dari hasil perhitungan diketahui $\mathrm{n}=28, \mathrm{k}^{\prime}=1$ dan $\alpha=0,05$ diperoleh nilai DWtebel $(\mathrm{dL})=1.328$ dan $\mathrm{dU}=1.476$. Nilai DWhitung (d) berada diantara nilai dU tabel dan nilai 4- dU tabel (dU < $d<4-d U)$. 


\section{Deteksi Autokorelasi Positif}

Jika d > dU : 1,889 >1,476 maka tidak terdapat autokorelasi positif.

Deteksi Autokorelasi Negatif:

Jika (4-d) $>$ dU : 2,111 > 1,476 maka tidak terdapat autokorelasi positif.

Maka dapat disimpulkan pada analisis regresi penelitian ini tidak terdapat autokorelasi positif dan tidak terdapat autokorelasi negatif sehingga bisa disimpulkan sama sekali tidak terdapat autokorelasi.

\section{Uji Multikolinieritas}

Dalam hasil perhitungannya diketahui bahwa nilai VIF untuk variabel Keputusan Nasabah memiliki nilai VIF berada pada kisaran variabel: Keputusan Nasabah $=1,000$. Nilai ini berarti kurang dari 10 dan dapat dilihat pula berdasarkan tabel 4.9 diatas hasil perhitungan nilai toleransi lebih dari 0,10. Jadi dapat disimpulkan bahwa tidak terjadi gejala multikolinieritas antar variabel bebas dalam persamaan regresi yang diperoleh.

\section{Uji Heteroskedasitas}

Berdasarkan hasilnya, menunjukkan bahwa titik-titik menyebar dan tidak membentuk pola tertentu. Dengan demikian dapat disimpulkan bahwa tidak terjadi heteroskedasitas, ini berarti bahwa data penelitian ini bersifat homogen.

\section{Analisis Regresi Linier Sederhana}

Berdasarkan dari hasil analisis regresi diketahui nilai konstantanya adalah 4,547. Artinya, ketika tidak adanya tambahan dari Pengetahuan Konsumen maka Keputusan Nasabahnya adalah 4,547\%. Hal ini menunjukan bahwa dengan setiap penambahan $1 \%$ tanggapan responden mengenai Pengetahuan Konsumen maka akan mempengaruhi Keputusan menjadi Nasabah pada PT. Bank Syariah Mnadiri KCP BSD yakni sebesar 0,313 atau $31,3 \%$.

Berdasarkan perhitungan, dapat diketahui korelasi (r) antara kedua variabel pengetahuan konsumen dan keputusan konsumen dengan menggunakan analisis korelasi pearson adalah sebesar 0.795. Bila dikonsultasikan pada tabel $\mathrm{r}$ product moment pearson taraf signifikan tabel $5 \%$ dengan df 28 maka t tabel adalah sebesar X sehingga dapat dilihat bahwa $r$ hitung $>r$ tabel dan berada pada nilai dengan taksiran kuat. Maka dapat disimpulkan bahwa antara variabel X (Pengetahuan Konsumen ) dengan variabel Y (Keputusan Konsumen) memepunyai korelasi yang positif yang artinya apabila pengetahuan konsumen meningkat, maka keputusan konsumen pun akan meningkat dan 
sebaliknya jika pengetahuan konsumen menurun maka keputusan konsumen pun akan menurun.

\section{Uji Hipotesis}

Dari hasil perhitungan didapatkan nilai $t$ hitung sebesar 6,937 dengan pvalue 0,000 sedangkan nilai $t$ tabel sebesar 1,701 . Hal ini berarti $0,000<$

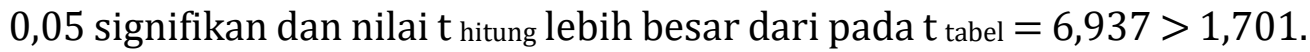
Dengan demikian, maka variabel X pada level 95\% $(\alpha=5 \%)$ dan degree of freedom $(\mathrm{df}=28)$ Ho ditolak dan Ha diterima. Hasil uji individu ini, membuktikan bahwa secara parsial terdapat pengaruh dan signifikan antara variabel Pengetahuan Konsumen dengan Keputusan menjadi nasabah di PT. Bank Syariah Mandiri BSD Tangerang Selatan.

\section{Analisis Koefisien Determinasi $\left(\mathrm{R}^{2}\right)$}

Berdasarkan perhitungan, diketahui nilai koefisien determinasi adalah sebesar 0,632. Hal ini berarti bahwa pengetahuan konsumen berpengaruh terhadap keputusan konsumen sebesar 63,2\%. Dari hasil perhitungan dapat disimpulkan bahwa ternyata pengetahuan konsumen memberikan pengaruh yang signifikan kepada keputusan konsumen sedangkan sisanya 36,8\% dipengaruhi oleh faktor lain diluar variabel X (Pengetahuan Konsumen) yang tidak diteliti.

\section{Kesimpulan}

Kesimpulan dari rumusan masalah yang diajukan, analisis data yang telah dilakukan dan pembahasan yang telah dikemukakan pada bab sebelumnya, maka dapat ditarik beberapa kesimpulan sebagai berikut:

1. Pengetahuan konsumen dengan indikator pengetahuan tentang karakteristik atau atribut produk atau jasa, faktor yang melekat secara langsung pada produk atau jasa, faktor yang melekat secara tidak langsung pada produk atau jasa, dan pengetahuan manfaat produk atau jasa (Manfaat Fungsional, Manfaat Psikososial) berada dalam kategori mengetahui secara baik.

2. Keputusan konsumen dengan indikator pengenalan masalah, pencarian informasi, evaluasi alternatif dan keputusan pembelian berada dalam kategori menentukan terhadap pengambilan keputusan.

3. Berdasarkan Analisis koefisien determinasi $\left(\mathrm{R}^{2}\right)$ adalah sebesar 0,632 . Hal ini berarti bahwa pengetahuan konsumen berpengaruh terhadap keputusan konsumen sebesar $632 \%$. Dari hasil perhitungan dapat disimpulkan bahwa ternyata pengetahuan 
konsumen memberikan pengaruh yang sangat signifikan kepada keputusan konsumen sedangkan sisanya 36,8\% dipengaruhi oleh faktor lain diluar variabel X ( Pengetahuan Konsumen ) yang tidak diteliti.

\section{Daftar Pustaka}

A.P Mangkunegara. Perilaku Konsumen, Edisi Revisi, Cetakan Keempat, Bandung: PT Refika Aditama, 2009.

Abduh Tuasikal, Muhammad. "Bunga Bank Itu Riba." Artikel diakses pada 05 Mei 2015 dari http://rumaysho.com/muamalah/bunga-bankitu-riba-1957.html

Antonio, Muhammad Syafi'i. Bank Syariah dari Teori ke Praktek, Jakarta: Gema Insani Press, 2001.

Arikunto, Suharsimi. Prosedur Penelitian: Suatu Pendekatan Praktek. Jakarta: Rineka Cipta, 1998.

Bank Indonesia dan Lembaga Penelitian dan Pengabdian Pada Masyarakat Universitas Hasanuddin. Penelitian, Potensi, Preferensi, dan Perilaku Masyarakat Terhadap Bank Syariah di wilayah Sulawesi Selatan. Bank Indonesia, Makassar, 2003.

Dajan, Anto. Pengantar Metode Statistik. Jakarta : PT Pustaka LP3ES, 1996. IAIN Sunan Ampel. Petunjuk Teknis Penulisan Skripsi. Cet IV Edisi Revisi, 2012.

Idat, Dhani Gunawan. Analisis Yuridis Pembentukan Undang-Undang Perbankan Syariah, dalam Buletin Hukum Perbankan dan Kebanksentralan Vol. 3, No. 1, April 2005, Jakarta : 2005, BI.

Keller, Kevin Lane. Manajemen Pemasaran, Edisi 13 Jilid 1, Alih Bahasa, Bob Sabran, Erlangga: Jakarta, 2008.

Kotler dan keller. Manajemen Pemasaran. Jakarta: Airlangga, 2008.

Kotler, Philip. Manajemen Pemasaran, Jakarta: IKAPI, 2000.

Kuncoro, Mudrajad. Metode Riset untuk Bisnis dan Ekonomi. Jakarta : Erlangga, 2003.

L.G, Schiffman dan Kanuk. Perilaku Konsumen, Jakarta: Ghalia Indonesia, 2004.

Laporan Tahunan. "PT. Bank Syariah Mandiri." Artikel diakses pada 25 Agustus 2015 dari http://www.Syariahmandiri.co.id

Moleong Lex J. Metodologi Penelitian Kualitatif. Bandung: Remaja Rosdakarya, 2004.

Muhammad. Bank Syariah_Analisis Kekuatan, Kelemahan, Peluang dan Ancaman.Yogyakarta : Ekonisia, 2004. 
Muhammad. Manajemen Bank Syariah. Yogyakarta : UPP AMP YKPN. 2002.

Nazir, Mohammad. Metode Penelitian. Jakarta : Ghalia Indonesia, 1999.

Noman, Abdullah M. "Inovasi Imperatif Keuangan Untuk Bank Islam", International Journal of Islamic Financial Services Vol. 4 No.3, Oktober 2002.

Paul, Peter J. Dan Olson, Perilaku Konsumen dan Strategi Pemasaran, Edisi ke Empat, Jilid I, Jakarta:Erlangga, 2006.

Rammal, H. G., Zurbruegg, R. Awareness of Islamic Banking Products Among Muslims: The Case of Australia. dalam Journal of Financial Services Marketing, Vol. 12 No.1, 2007.

Santoso, Singgih. Mengolah Data Statistik Secara Profesional. Jakarta: PT Elex Media Komputindo, 2001.

Setiadi, Nugroho J. Perilaku Konsumen Konsep dan Implikasi untuk Strategi dan Penelitian Pemasaran. Jakarta : Prenada Media, 2003.

Setiadi, Nugroho J. Perilaku Konsumen, Konsep dan Implikasi Untuk Strategi dan Pemasaran, Jakarta: Erlangga, 2000.

Simamora, Bilson. Panduan Riset Perilau Konsumen, Jakarta: Gramedia Pustaka Utama, 2002.

Sofian effendi, M. Singarimbun. Metode Penelitian Survei. Edisi Revisi. Jakarta : LP3ES, 1995.

Sumarwan, Ujang. Perilaku Konsumen Teori dan Penerapanya dalam Pemasaran, Jakarta: Ghalia Indonesia, 2011.

Surya, Cholid. "Pengetahuan Produk." Artikel diakses pada 01 Agustus 2015 dari

http://suryaafrilian.blogspot.com/2010/10/pengetahuanproduk 27.html

Suryabrata, Sumardi. Metodologi Penelitian. Jakarta: PT. Raja Grafido Persada, 2010

Sutisna. Perilaku Konsumen dan Komunikasi Pemasaran, Bandung: PT Remaja Rosdakarya, 2002.

Sutisna. Perilaku Konsumen dan Komunikasi Pemasaran. Bandung : PT Remaja Rosdakarya, 2003.

Sutjipto. "Pengertian Minat." Artikel diakses pada 06 Mei 2015 dari http://definisionline.blogspot.com/2010/09/definisi-minat.html

Syafi'i Antonio, Muhammad. Bank Syariah dari Teori ke Praktek. Jakarta : Gema Insani, 2001.

Umar, Husein. Metode Penelitian untuk Skripsi dan Tesis Bisnis. Jakarta: PT Raja Grafindo Persada, 1999.

Wardiah, Mia Lasmi. Dasar- Dasar Perbankan, Bandung: CV Pustaka Setia, 2013. 